
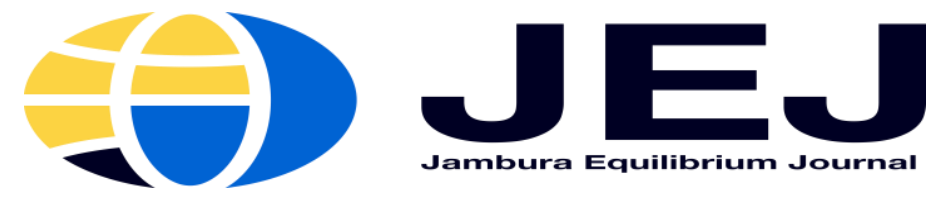

Volume 1. Number 2. July 2019

P-ISSN 2655-9110

E-ISSN 2656-0445

http://ejurnal.ung.ac.id/index.php/equij

\title{
The Effect Of Government Spending For Economic Structure Changes In Gorontalo Province
}

\author{
Dyna Pratama Gobel ${ }^{1}$, Fitri Hadi Yulia Akib ${ }^{2}$ \\ Department of Economic Development, Economic Faculty, Gorontalo State University ${ }^{1}$ \\ Faculty of Economics, Gorontalo State University ${ }^{2}$
}

\begin{abstract}
This study aims to determine the extent of the effect of government spending on changes in economic structure in Gorontalo Province 2011-2016. This study uses panel data regression analysis, with quantitative descriptive methods. and to calculate the shift in structure in Gorontalo Province using the formula (Structural Change Index). The results showed that Government spending directed at economic development in the Province of Gorontalomen showed a positive effect, meaning that the role of the primary sector was increasing so that it did not have an impact on changes in economic structure.
\end{abstract}

\section{Keywords: Government Spending, Economic Structural Change}

Economic development in a region is a process in which the regional government and its people manage existing resources and form a partnership pattern between the regional government and the private sector to create a new job opportunity and stimulate the development of economic growth in the region. Therefore, local governments and their community participation by using existing resources must be able to estimate the potential resources needed to design and build the regional economy (Arsyad, 1999).

To realize a development, especially for the region itself in the sense of advancing an area, it requires a process of development that will certainly incur costs or incur government spending. With the existence of development in a region, it can be seen that the contribution made by development priorities in particular through increasing the economic value added through the structure of the agricultural economy, industry, and also productive services. These priorities are part of the government structure to carry out the expenditure or financing of the economic structure that is a determining factor of a country's national income in the national development process. 
The role of the government is very important in financing state or government activities in order to realize its function in carrying out welfare. In the book Marzuki
Ilyas (1989: 38) government spending involves all expenditures to finance its activities, these expenditures are aimed at achieving the welfare of society as a whole.

Table 1 Realization of Capital Expenditures, Services Goods, and Social Financing

\begin{tabular}{|c|c|c|c|}
\hline Year & $\begin{array}{c}\text { Capital } \\
\text { Expenditure }\end{array}$ & Service Goods & Social Financing \\
\hline 2011 & 141.984 .542 .254 & 225.445 .500 .999 & 6.898 .426 .209 \\
\hline 2012 & 138.397 .573 .651 & 248.669 .037 .594 & 39.250 .000 \\
\hline 2013 & 206.857 .423 .883 & 323.846 .965 .135$. & 19.209 .486 .000 \\
\hline 2014 & 232.424 .743 .197 & 297.917 .117 .074 & 20.936 .253 .500 \\
\hline 2015 & 344.244 .075 .019 & 429.398 .453 .510 & 17.190 .031 .226 \\
\hline 2016 & 296.922 .957 .084 & 446.991 .903 .797 & 24.596 .437 .000 \\
\hline
\end{tabular}

Source: The Ministry of Finance of the Republic of Indonesia 2018

For capital expenditure from 2011 to 2015, an increase of Rp.344,244,075,019. until 2016 it decreased by Rp.296,922,957,084. For Goods and Services Expenditures in 2011 to 2014 experienced funds that fluctuated by Rp.297,917,117,074. Then in 2015 to 2016 it increased by Rp.446,991,903,797. while for social financing from 2011 to 2014 it has increased with a total value of Rp. 20,936,253,500 up to 2015 decreased by Rp.17,190,031,226 and in 2016 increased again with the total value of funds of Rp. 24,596,437,000.

On the other hand, each sector has changed from year to year. From 2011 to 2016 the agriculture, fisheries and forestry sectors are still the most dominant sectors in their distribution of GRDP in Gorontalo Province. Then in second place is the construction sector in 2016 with a value of $2849.81 \%$. and the third largest sector was the wholesale and retail sectors of car and motorcycle repair in 2016 which rose by $2500.71 \%$. then followed by other sectors, namely the Government Administration sector, defense and mandatory social security namely in 2016 increased by $1976.61 \%$, the transportation and warehousing sector in 2016 rose by $1410.38 \%$. the financial and insurance services sector increased by $968.83 \%$, followed by other sectors, namely the education service sector by $994.83 \%$, the 
manufacturing industry sector by $941.23 \%$, the health and social services sector by $871.82 \%$, the information and communication sector by $710.71 \%$, the sector provision of food and drink accommodation by $580.73 \%$, the real estate sector by $524.98 \%$, then other service sectors by $406.47 \%$, the mining and quarrying sector by an average of $294.53 \%$, the company's service sector by $22.57 \%$, the electricity and gas procurement sector by $17.42 \%$, and the most recent sector is the water supply sector, recycled waste processing waste by an average of $12.06 \%$.

Structural transformation is the process of changing the structure of the economy from the agricultural sector to the industrial, trade and service sectors, where each economy will undergo different transformations. In general, the transformation that occurs in developing countries is the transformation from the agricultural sector to the industrial sector. Changes in the structure or transformation of the economy from traditional to modern can generally be defined as a change in the economy related to the composition of labor absorption, production, trade, and other factors that are needed continuously to increase income and social welfare through increasing income per capita (Chenery 1986).
With the enactment of Law No. 22/1999 concerning Regional Autonomy and Law No. 25 of 1999 concerning Fiscal Balance, which was updated with Law No. 32 of 2004 concerning Regional Government and Law No. 33 of 2004 concerning Fiscal Balance between the Central Government and Regional Governments, the regional authority in regulating and managing the interests of the community through its own initiatives, the regional government in carrying out development in its region has the authority to determine the direction of development in its area. This is expected to further enhance regional development in accordance with the needs of the region and be able to realize community welfare. In line with national development, the role of the Regional Government in the implementation of regional development continues to be strived to increase further. This is intended to realize more real and responsible regional autonomy.

Preparation of regional development plans and policies that apply must always consider the capabilities and potential of each region, so that the development efforts that take place in each region are really in accordance with the conditions of each region. Economic development that is carried out is directed 
to create changes in economic structure that are more competitive and have high added value and are likely to cause increased economic growth and increased income (Hamzah, TT: 2).

In the framework of the implementation of development, it is necessary to improve the ability to manage and the ability to develop the region. Among the ability to manage is managing the Regional Revenue and Expenditure Budget which is a quantitative elaboration of the goals and objectives of the Regional Government as well as the main tasks and functions of the work unit, so that the regional budget is an inseparable part of the entire regional development planning process. The budget is also a reflection of the financial economy of the community and people's choices.

\section{METHODS}

This research departs from the issue of Government Expenditure directed at economic development in Gorontalo province which has not been able to change the economic structure from the traditional (primary) sector to the modern (secondary) sector. The study aims to see whether the influence of government spending is significant to changes in economic structure in Gorontalo province. The independent variable is capital expenditure, service goods expenditure, and social financing, while the dependent variable is the change in structure. This study uses panel data regression analysis and uses quantitative descriptive methods, namely by collecting data on Government Spending and Changes in Economic Structure in the time series.

RESULTS AND DISCUSSION

Tabel : 2

Regression Analysis Results of the Effects of Government Spending on Changes in Economic Structure

\begin{tabular}{|c||c||c||c||}
\hline \hline Variabel & Coefficient & Std.Error & t-Statistic \\
\hline \hline C & 1.754816 & 3.922 .217 & 0.447404 \\
@ LOG(BM?) & 0.334743 & 0.151952 & $2.202953^{* *}$ \\
@LOG(BJ?) & -0.2994321 & 0.107455 & $-2.739021^{\text {*** }}$ \\
@LOG(PS?) & -0.104076 & 0.034377 & $-3.027511^{\text {*** }}$ \\
\hline \hline R-squared & 0.418353 & \\
Adjusted R-squared & 0.351239 & & \\
F-statistic & 6.233 .541 & & \\
Durbin-Watson stat & 1.969 .326 & &
\end{tabular}


Source : E-views, 2019 (Note: Signification *) 10\%**) 5\%***) 1\%

capital expenditure shows a positive value to the primary sector which means the positive value means the superiority of the primary sector compared to the secondary and tertiary sectors. while for the variable expenditure on service goods and social finance shows the results of a negative influence, meaning that there is a change in structure. Although the change is not too significant because the allocation of goods and services expenditure and negative social financing will be followed by a decrease in the structural change index value. Which means the role of the primary sector will decline so that it has an impact on structural changes. Or it can be assumed by spending more or more it can have the effect of a shift in economic structure with the increase in the secondary and tertiary sectors.

However, in Gorontalo Province it is still dominated by the agricultural sector. In my opinion this is because the area of land for agriculture in Gorontalo is more than the land in the development of an industry in accordance with the Gorontalo Province spatial plan. Although there are several land sites in the industrial development that already exist, but have not had time to be filled according to the specified capacity. With this reality, the comparison between agricultural land and industrial land when compared to industrial activities is still greater than the area of agricultural land. Furthermore, in terms of aspects of Human Resources or labor, the number of residents who work in Gorontalo Province, the agricultural sector is still the biggest absorber of labor in Gorontalo Province compared to industrial activities. In addition, residents of Gorontalo Province are still not interested in carrying out industrial activities. Because it is caused by the development in the industrial sector, it requires a lot of funds.

Based on the output above the regression model for the effect of the level of government spending on changes in economic structure in the district / city in Gorontalo Province, the following things can be interpreted:

1. If the influence of all independent variables (capital expenditure, goods and services expenditure, and social financing) is ignored, the average structural change index of the regency / city index in Gorontalo Province during 2011-2016 is $1.75 \%$.

2. Capital expenditure allocation has a positive effect on changes in economic 
structure. An increase in capital expenditure allocation of $1 \%$ will be followed by an increase in the structural change value of the district / city index in Gorontalo Province by an average of $0.33 \%$.

3. Spending on goods and services has a negative effect on changes in economic structure. An increase in goods and services expenditure allocation of $1 \%$ will be followed by a decrease in the structural change value of the district / city index in Gorontalo Province by an average of $0.29 \%$.
4. The level of social financing has a negative effect on changes in economic structure. An increase in social expenditure allocation of $1 \%$ will be followed by a decrease in the structural change index of the district / city index in Gorontalo Province by an average of $0.10 \%$.

Explicitly the results of testing the significance of the effect of each variable on changes in economic structure in all districts / cities of Gorontalo Province are as follows:

Table 3

T test Result

\begin{tabular}{|l|c|c|c|c|}
\hline \multicolumn{1}{|c|}{ Variabel } & Df 2 & A & t-tabel & t-hitung \\
\hline Capital Expenditures & 33 & $10 \%$ & $1,30 \%$ & 0,0367 \\
\hline $\begin{array}{l}\text { Shop for Goods \& } \\
\text { Services }\end{array}$ & 33 & $5 \%$ & $2,03 \%$ & 0,011 \\
\hline Social Funding & 33 & $1 \%$ & $2,44 \%$ & 0,0055 \\
\hline
\end{tabular}

Source: Data Processed 2019

1. Effect of Capital Expenditure Allocation on the Level of Economic Structure

From the analysis that has been done, the results show that capital expenditure has a positive effect on the growth of the level of economic structure in the districts / cities in Gorontalo Province during 2011-2016.
While the partial test results show there is a significant influence of the allocation of capital expenditure on the level of economic structure. According to PP number 24 of 2005, capital expenditure is a budget expenditure to obtain other fixed assets that benefit more than one accounting period. Capital expenditure, namely: land 
capital expenditure, equipment and machinery expenditure, capital expenditure and other capital expenditure building.

Regional expenditure in the form of capital expenditure is an expenditure for investment. According to Sukirno (2006) investment activities enable a community to continuously improve economic activities and employment opportunities, increase national income, and increase the level of prosperity of the community. Therefore, with the increase in the value of capital expenditure, it will have an impact in the coming period, namely increasing community productivity and increasing investors will increase local revenue (Hariyanto and Adi, 2002).

This research is in line with research by Mardiasmo (2002). Development expenditure is direct expenditure which is used to finance investment or increase assets. In this case 11 government capital expenditures play a role as social everhead capital (SOC) which attracts the private sector to invest their capital. With the function of public facilities provided by this government will encourage economic growth and increase local revenue.
2. Effects of Spending on Goods and Services on the Level of Economic Structure

From the analysis that has been done, it is obtained that the allocation of expenditure for goods and services has a negative influence on the increase in the level of economic structure. The negative regression coefficient would indicate an increase in the allocation of spending on goods and services would actually have an impact on the decline in the value of the structural change index of the region.

Classification According to Government Regulation No. 71 of 2010 regarding accounting standards that goods and services expenditure is included as part of the classification of operating expenditure, namely budget expenditures for daily activities of the central or regional government that provide benefits in the short term. Which means Shopping for Goods or Services does not have a long useful life or are consumable.

This research is in line with that proposed by Bonet (2006), this relates to spending behavior that is generally used for wages and salaries not for investment and infrastructure development, as well as the absence of 
adequate incentives from the central government and the lack of institutional capacity of local governments.

3. Effect of Social Financing on economic structure

From the analysis that has been done, the results show that social financing has a negative and significant effect on the level of economic structure in the districts / cities of Gorontalo Province during 2011-2016.

According to Kasmir (2008: 96). Social Financing is a transfer of the provision of money or goods given by the central or regional government to the community. To protect from possible risks. If from the occurrence of these risks will get in the form of social assistance funds that will support the development process that is likely to occur problems. So for Social Financing it is only helping or spending funds in the form of social assistance. The Social Funding Is a fund that can be used for other needs besides for disaster relief but can also be used for purposes in entrepreneurship.

This research is in line with Nurlan (2008), that unexpected expenditure or social financing is expenditure that is carried out by local governments to finance unexpected activities and extraordinary events. Whereas unexpected expenditure activities are expenditures for activities which are unusual or not expected to recur, such as overcoming natural disasters and social disasters that are not foreseeable, including returns on excess and regional revenues from previous years.

\section{CONCLUSION}

\section{1). Capital Expenditures}

From the results of the discussion in the previous chapter, capital expenditure allocation has a positive effect on changes in economic structure in Gorontalo Province. This means that the role of the primary sector increases with the decline of the secondary and tertiary sectors. In this case, which means that there has been no change in the economic structure in Gorontalo Province.

2). Shop for Goods and Services

From the results of the discussion in the previous chapter that the allocation of expenditure for goods and services negatively affects changes in economic structure, which means the role of the primary sector decreases and the increase in the secondary and tertiary sectors, so that it impacts on changes in economic structure. although it has not 
really shown any significant changes to the economic structure in Gorontalo Province. this is because shopping for goods and services is spending that is only consumable.

3). Social Funding

From the results of the discussion in the previous chapter that the allocation of social financing has a significant negative effect, which means the decline in the primary sector decreases with increasing secondary and tertiary sectors. thus impacting on changes in economic structure. although it has not really shown any significant changes to the economic structure in Gorontalo Province. because social funding is funds that are only in the form of assistance or funds incurred if there are urgent needs or unexpected problems.

\section{REFERENCES}

Afiat. M. N. (2015). Analisis Pengaruh Pengeluaran Pemerintah Terhadap Perubahan Struktur Ekonomi di Provinsi Sulawesi Tenggara. Jurnal Ekonomi Pembangunan. Vol 16. No. 08. hal 20-26.

Alexandra Hukom. (2014). Hubungan Ketenagakerjaan Dan Perubahan Struktur Ekonomi Terhadap Kesejahteraan Masyarakat :
Palangkaraya. Jurnal Ekonomi. hal. 120-129

Anita Roosmawarni, Soekarnoto. (2015). Analisis pertumbuhan ekonomi dan transformasi struktural Di provinsi jawa timur Tahun 2000 - 2010. Jurnal Ekonomi dan Bisnis. Vol. 25. No.01 hal. 01-13.

Aprillia, P. M. (2014). Pengaruh pertumbuhan ekonomi Sektor primer, sekunder, tersier, dan Tingkat upah terhadap penyediaan Lowongan kerja tamatan smk di Provinsi jawa tengah. Skripsi Ekonomi dan Bisnis : Semarang.

Arham, M. A. (2012). Desentralisasi Fiskal dan Perubahan Struktur Ekonomi Studi Perbandingan Kawasan Sulawesi dan Jawa : Jurnal Ekonomi dan Keuangan. Vol.18 No.80. hal 431-451.

Arham, M. A. (2014). Kebijakan Desentralisasi Fiskal Pergeseran Sektoral dan Ketimpangan antar kabupaten/kota di Sulawesi Tengah: Jurnal Ekonomi dan Pembangunan Indonesia. Vol.14 No.2, hal 145-167. Badan Pusat Statistik. (2018). PDRB ADHK Tahun 2010 Berdasarkan lapangan Usaha : Provinsi Gorontalo. Dina Apriana, Rudy Suryanto. (2010). "Analisis Hubungan Antara Belanja 
Modal, Pendapatan, Asli Daerah, Kemandirian Daerah, dan Pertumbuhan Ekonomi Daerah". Jurnal Ekonomi Akuntansi. Vol. 11 No 1, hal 68-79.

Ferry Prasetya, SE. (2012). Teori Pengeluaran Pemerintah. Modul ekonomi publik Bagian $\mathrm{V}$. Universitas Brawijaya. Makalah Ekonomi : Malang.

Harsono, I. (2013). Dampak Perubahan Struktur Ekonomi Terhadap Penyerapan Tenaga Kerja Di Provinsi Nusa Tenggara Barat (Pendekatan Input Output). Jurnal Ekonomi : Mataram.

Jhingan ML. (2002). Ekonomi

Pembangunan. Penerbit Rajawali : Jakarta.

Kementerian Keuangan RI (Kemenkeu).

Data APBD 2011-2016 :

Kemenkeu.go.id

Ketut Kariyasa. Perubahan struktur ekonomi dan kesempatan kerja Serta kualitas sumberdaya manusia di indonesia. Jurnal Ekonomi.

Latumaerissa, J. R. Perekonomian Indonesia dan Dinamika Ekonomi Global. Indonesian Economy and Global Economi Global. (penerbit), Mitra Wacan Media.
Louhenapessy, D. J. (2014). Perhitungan Indeks Perubahan Struktur ( Stuctural Changes Index) pada sektor perekonomian di Kota Ambon.Jurnal Ekonomi. Vol.08. No.1. hal 01-19.

Ma'rifah. A. N. (2017). Struktur perekonomian dan Pertumbuhan Ekonomi. Skripsi Ekonomi Islam : Bandar Lampung.

Merri Anitasari, Ahmad Soleh. Pengaruh Pengeluaran Pemerintah Terhadap Pertumbuhan Ekonomi di Provinsi Jambi. Jurnal Ekonomi : Bengkulu.

Merlin Anggraeni. (2017). Analisis Pengaruh Pengeluaran Pemerintah Di Sektor Pendidikan, Kesehatan, Dan Pertanian Terhadap Pertumbuhan Ekonomi Indonesia Periode 1970-2015. Skripsi Ekonomi : Yogyakarta.

M.Zahari MS. (2017). Pengaruh Pengeluaran Pemerintah Terhadap Pertumbuhan Ekonomi di Provinsi Jambi. Jurnal of Economics and Business Vol.1 No.1 hal. 01-17.

Setiawan, A. O. (2016). "Analisis Perubahan Struktur Ekonomi”. ADLN - Perpustakaan Universitas Airlangga : Surabaya.

Sofyan Sauri. (2018). Analisis Peranan Sektor Primer-Sekunder-Tersier terhadap Laju Pertumbuhan Ekonomi 
Studi kasus Provinsi Banten Tahun 2007- Tahun 2017. Makalah Ekonomi : Bandung.

Sri Kusreni. (2009). Pengaruh perubahan struktur ekonomi terhadap spesialisasi sektoral dan wilayah serta struktur Penyerapan tenaga kerja sektoral untuk daerah Perkotaan di jawa timur. Fakultas Ekonomi Airlangga.
Tarmidi Lepi T. (1992). Ekonomi Pembangunan: Jakarta.

Tumandung, M. (2014). Pergeseran struktur perekonomian Di provinsi sulawesi utara. Jurnal Ekonomi : Manado.

Yudha Prawira, Wahyu Hamidi. (2013). Transformasi struktur ekonomi kabupaten siak Tahun 2001-2010 : Jurnal Ekonomi. Vol.2.No.1, hal 0121. 